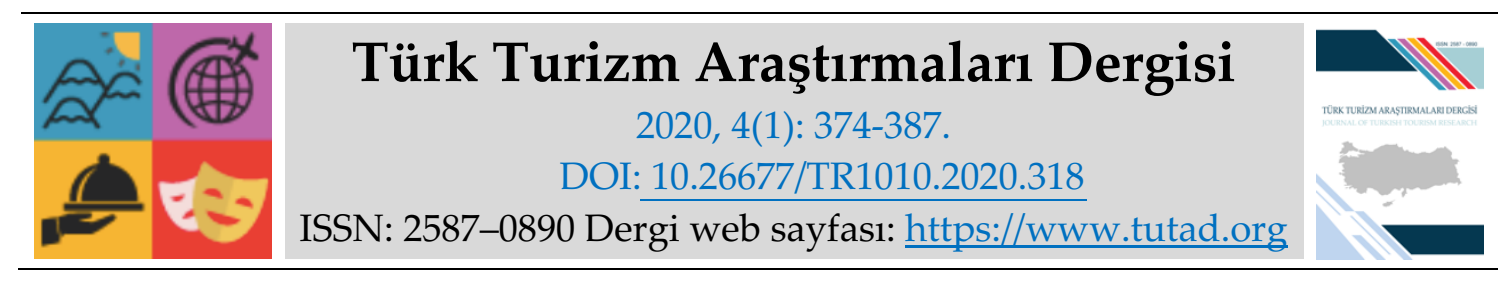

ARASTIRMA MAKALESİ

\title{
Adalet Algısı Boyutlarının Şikâyet Sonrası Davranışlar Üzerine Etkileri: Konaklama İşletmeleri Üzerine Bir Uygulama*
}

Doç. Dr. Pınar BAŞGÖZE, Hacettepe Üniversitesi, İktisadi ve İdari Bilimler Fakültesi, Ankara, e-posta: pinaran@hacettepe.edu.tr ORCID: https://orcid.org/0000-0003-4597-5752

Kübra İŞKORKUTAN, Yüksek Lisans Öğrencisi, Hacettepe Üniversitesi, Sosyal Bilimler Enstitüsü, Ankara, e-posta: k.iskorkutan@gmail.com

ORCID: https://orcid.org/0000-0002-0067-473X

$\ddot{O} z$

Çalışmanın amacı tüketicinin şikâyet sonrası davranışları üzerine hizmet telafisi ölçüm yöntemlerinden biri olan adalet algısı boyutlarının etkilerini saptamaktır. Buna göre çalışmada adalet algısı boyutları olarak bilinen prosedürel, etkileşimsel ve dağıtımsal adalet algılarının; şikâyet sonrası davranışlar olan tekrar satın alma eğilimi ve olumsuz kulaktan kulağa iletişim üzerine etkileri saptanmaya çalışılmıştır. Çalışmada yarı-deneysel bir tasarım oluşturulmuştur. Adalet algısı boyutlarının farklı düzeylerine göre on iki senaryo üretilmiş, her bir senaryo için 20-23 katılımcı olacak şekilde toplam 270 adet veri kullanılmıştır. Çalışmanın sonuçlarına göre, yüksek düzeyde etkileşimsel ve prosedürel adalet algısı deneyimleyen ziyaretçiler daha fazla tekrar satın alma eğilimi ve daha az olumsuz kulaktan kulağa iletişim eğilimi gösterebileceklerdir. Beklenilenin aksine konaklama işletmelerinde şikâyet davranışında bulunan ziyaretçilerin dağıtımsal adalet algıları (örn. indirim ya da geri ödeme) tekrar satın alma ve olumsuz kulaktan kulağa iletişim eğilimlerini etkilememektedir.

*Bu makale Kübra İşkorkutan'ın Hacettepe Üniversitesi'nde yazmış olduğu yüksek lisans tezinden çıkarılmıştır.

Anahtar Kelimeler: Konaklama İşletmeleri, Şikâyet Davranışı, Hizmet Telafisi, Adalet Algısı.

Makale Gönderme Tarihi: 20.10.2019

Makale Kabul Tarihi: 08.01.2020

\section{Önerilen Atıf:}

Başgöze, P. ve İşkorkutan, K. (2020). Adalet Algısı Boyutlarının Şikâyet Sonrası Davranışlar Üzerine Etkileri: Konaklama İşletmeleri Üzerine Bir Uygulama, Türk Turizm Araştırmaları Dergisi, 4(1): 374-387. (C) 2020 Türk Turizm Araştırmaları Dergisi. 


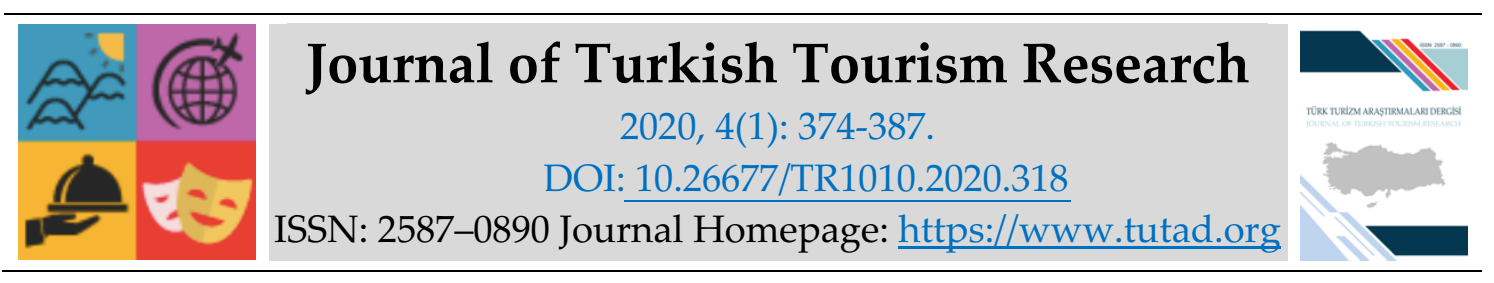

\title{
$\underline{\text { RESEARCH PAPER }}$
}

\section{The Effects of Perceived Justice Dimensions on Post-Complaint Behaviors: Hospitality Management Case}

Associate Prof. Dr. Pınar BAŞGÖZE, Hacettepe University, Faculty of Economics and Administrative Sciences, Ankara, e-mail: pinaran@hacettepe.edu.tr

ORCID: https://orcid.org/0000-0003-4597-5752

Kübra İŞKORKUTAN, MSc. Student, Hacettepe University, Social Sciences Institute, Ankara, e-mail: k.iskorkutan@gmail.com

ORCID: https://orcid.org/0000-0002-0067-473X

\begin{abstract}
The purpose of this study is to examine the effects of justice dimensions which are one of the measurement ways of service recovery on consumer's post-complaint behaviors. Thus, in this study the effects of distributive, interactional and procedural justice which are known as justice perception dimensions on repurchase intention and negative word of mouth was investigated. Quasi-experimental design was conducted and twelve scenarios were created according to different levels of justice perception dimensions. Twelve scenarios were created according to the different levels of justice perception dimensions and 270 data were used for each scenario with 20-23 participants. The results indicate that, visitors who experience a high level of interactional and procedural justice of perception may tend to increase repurchase behavior and may decrease negative word of mouth communication intentions. Contrary to expectations, distributive justice (e.g. discount or reimbursement) does not have a significant effect on consumers repurchase and negative word of mouth communication intentions.
\end{abstract}

Keywords: Hospitality Management, Consumer Complaint, Service Recovery Process, Justice Perception.

Received: 20.10 .2019

Accepted: 08.01.2020

\section{Suggested Citation:}

Başgöze, P. and İşkorkutan, K. (2020). The Effects of Perceived Justice Dimensions on Post-Complaint Behaviors: Hospitality Management Case, Journal of Turkish Tourism Research, 4(1): 374-387.

(C) 2020 Türk Turizm Araştırmaları Dergisi. 


\section{GİRIŞ}

Algılanan adalet hizmet alıcısının davranışları üzerine güçlü etkileri olması nedeni ile hizmet pazarlaması alanında önemli bir yere sahiptir (Migacz vd., 2018). Hizmet satın alan tüketicilerin tatmin düzeyleri ve davranışları bir nebze de telafi sürecine ilişkin adalet algılarına bağlıdır (Nikbin ve diğerleri, 2010). Farklı yazarlar (ör. Cantor vd., 2018) farklı hizmet sektörlerinde (ör. havayolları, restoran, konaklama işletmeleri vb.) adalet algısı boyutlarının müşteri tatmini üzerine etkilerini incelemişlerdir. Bir grup çalışma da (Smith vd., 1999; Blodgett vd., 1997; Maxham ve Netemayer, 2002) adalet algısı boyutlarının farklı düzeylerine göre şikâyet sonrası davranışlarını (tekrar satın alma eğilimi veya olumsuz kulaktan kulağa iletişim vb.) farklılaşıp farklılaşmadığını incelemişlerdir. Literatürde adalet algısının şikâyet sonrası davranışlar üzerine etkilerini inceleyen çalışmalar oldukça eskilere dayanmaktadır (örn. Clemmer ve Schneider, 1996). Ancak adalet algısı boyutları arasındaki etkileşimi incelemek ve bu bileşimlerden hangisinin tekrar satın alma ve olumsuz kulaktan kulağa iletişim eğilimleri üzerinde daha fazla etkiye sahip olduğunu görmek şikâyet davranışı ve adalet algısı çalışmalarına derinlik katabilecektir.

Turizm işletmelerinin amacı ilk kuruldukları dönemlerden bu yana; müşterilerine kaliteli hizmet sunmak, buna bağlı olarak da müşteri tatmini ve müşteri devamlılığı sağlamaktır. Müşteri devamlılığı, sadık müşterilerin daha fazla ödeme eğilimleri olması, daha fazla sayıda ve daha sık satın alma eğilimleri olması nedeni ile önem taşımaktadır. Turizm, büyük ölçüde hizmetin kendine has özelliklerini taşımaktadır, bu nedenle turizm sektöründe yer alan hizmet sağlayıcıları da ziyaretçilerine sunduğu çıktılarda standartlaşma sağlayamamakta ve hata yapabilmektedirler. Hizmetin soyut olma, standartlaştııılamama vb. özellikleri hizmet sağlayıcılarını somut mamule oranla daha fazla şikâyet ile karşı karşıya getirebilmektedir (Haverila ve Naumann, 2009:74). Bu nedenle, konaklama yönetiminin başarısında ve müşteri sadakati sağlamada konaklama işletmelerinde meydana gelen hizmet hatalarına uygun hizmet telafisi stratejileri ile çözüm bulmak da stratejik bir rol oynamaktadır. Şikâyetlerle etkin bir şekilde ilgilenmenin, müşterilerin perakende deneyimlerini değerlendirmelerinde önemli bir etkiye sahip olabileceğinin yanı sıra (Bitner vd., 1990; Kelley vd., 1993) tekrar satın alma eğilimlerini artırabilecek ve olumsuz kulaktan kulağa iletişimin yayılmasını azaltabilecektir (Blodgett vd., 1993; Gilly ve Gelb, 1982).

Buradan hareketle çalışmanın amacı; konaklama işletmeleri ziyaretçilerinin şikâyet sonrası davranışları üzerine hizmet telafisi ölçüm yöntemlerinden biri olan adalet algısı boyutlarının etkilerini saptamaktır. Buna göre çalışmada adalet algısı boyutları olarak bilinen prosedürel, etkileşimsel ve dağıtımsal adalet algılarının; hizmet hata sonrası davranışlardan olan konaklama işletmesinden tekrar hizmet satın alma eğilimi ve konaklama işletmesi ile ilgili olumsuz kulaktan kulağa iletişim üzerine etkileri saptanmaya çalışılmıştır.

\section{KURAMSAL VE KAVRAMSAL ÇERÇEVE}

\section{Hizmet Telafisi ve Adalet Algisı}

Hizmet hatasından kaçınmaya imkân yoktur (Sengupta vd., 2015). Bu sebeple işletmeler tüketicileri elinde tutabilmek için başarılı hizmet telafi stratejileri geliştirmek durumundalardır (Harun vd., 2019). Literatürde hizmet telafisine ilişkin olarak ilk tanım, Bell ve Zemke (1987) tarafından "hizmet işletmelerinin müşteri beklentilerini karşılamadığı zaman müşteriyi tekrar memnun etmek için planlanan işlemler" şeklinde yapılmıştır. Hizmet telafisi, şikâyetlerin verimli bir şekilde ele alınması ve bir müşterinin işletmeyle olan sorununu çözmeye çalışmak için hizmet sağlayıcıları tarafından gerçekleştirilen tüm eylemleri içermektedir (Grönroos, 1990). Böylece, telafi süreci ile birlikte tatmin 
olmamış bir müşteriyi tatmin olmuş bir müşteri haline dönüştürmek amaçlanmaktadır (Sparks ve McColl Kennedy, 2001).

Yapılan çalışmaların birçoğu (örn. Zemke ve Anderson, 2007) tüketicilerin bir hizmet hatası ile karşılaştıklarında ilk önce adil bir çözüm istediklerini ortaya koyuştur. Adalet algısı kavramına göre müşterilerin tatmin düzeyleri ve gelecekte işletmeye karşı gösterecekleri tutumlar, kendilerine adil davranılıp davranılmadığını hissetmelerine bağlı olarak şekillenmektedir (Chen ve Kim, 2019). Algılanan adalet; dağıtımsal, etkileşimsel ve prosedürel adalet olmak üzere üç boyutlu bir yapıya sahiptir. Dağıtımsal adalet; müşterilerin telafi sürecinde elde ettikleri somut çıtıların (ör. para iadesi) adil algılanmasıdır. Prosedürel adalet, hizmet telafi politika ve usullerinin (ör. telafi sürecinin hızı) adil algılanması anlamına gelir. Etkileşimsel adalet ise, hizmet sağlayıcı ile müşteri arasındaki kişisel iletişimlerin (ör. kibar davranmak) adil olarak algılanması ile ilgilidir (Blodgett vd., 1997). Algılanan adaletin çok boyutlu bir yapıya sahip olması nedeniyle, tüketici davranışları üzerine etkilerinin de boyutlara göre farklılaştırılarak incelenmesi önerilmektedir (Carrillo vd., 2019). Somut telafilerin bireyler tarafından adaletli algılanmasının yanı sıra telafi süreci ve yönetici ile çalışanın bu süreçteki tutum ve davranışları tüketicilerin telafi sonrası tatmin düzeylerini ve sonrasındaki davranışları etkileyebilecektir (Ding ve Lii, 2016). Daha önce bir takım çalışma algılanan adalet boyutlarından tatmin üzerine en fazla etkisi olanı saptamaya çalışmıştır (Mansori vd., 2014). Adalet algısı boyutlarının şikâyet sonrası davranışlar üzerine ayrı ayrı etkilerinin yanı sıra boyutların birlikte etkilerinin incelenmesi telafi stratejisi geliştirmek adına önem taşımaktadır. Dolayısıyla, algılanan adalet boyutlarının şikâyet sonrası davranışlar üzerine de (olumsuz kulaktan kulağa iletişim ve tekrar satın alma eğilimi) etkilerinin incelenmesi anlamlı olabilecektir.

\section{İLGILII ÇALIŞMALAR}

\section{Olumsuz Kulaktan Kulağa İletişim Kavramı ve Adalet Algısı İlişkisi}

Arkadaş ve akraba gibi biçimsel olmayan kaynaklardan edinilen bilgiler içeren kulaktan kulağa iletişim, firma tarafından yönetilen biçimsel kaynaklara göre (reklam vb.) tüketiciler tarafından daha güvenilir olarak algılanabilmekte ve tüketicilerin davranışları üzerine daha etkili olabilmektedir (Kotler ve Armstrong, 2004: 476). Böylece söz konusu bilgi tüketiciler arasında kolayca yayılabilmektedir. Dikkat çekici olan nokta ise olumsuz kulaktan kulağa iletişimin; mevcut bilgilerden ve olumlu kulaktan kulağa iletişimden daha fazla yayılma eğiliminde olmasıdır (Baumeister vd., 2001). Bu nedenledir ki, işletmeler olumsuz kulaktan kulağa iletişimi kontrol edebildikleri değişkenler aracılığı ile azaltmaya çalışırlar.

Yapılan çalışmalar hizmet telafisi ve algılanan adalet boyutlarının kulaktan kulağa iletişim üzerine anlamlı etkilerini saptamıştır (Chen ve Kim, 2019; Harun vd., 2019). Dolayısıyla işletmeler hizmet telafisi stratejilerinin yardımıyla tüketicilerin başlattıkları kulaktan kulağa iletişimi yönetebileceklerdir. Hızlı ve uygun yöntemler ile sunulan hizmet telafisi tüketicilerin telafi sonrası tatmin olmalarını sağlayabilecek ve olumlu kulaktan kulağa iletişim eğilimlerini artırabilecekti (Chih-Hung vd., 2019). Literatürde benzer bulguyu farklı ifade eden çalışmalar da mevcuttur. Örneğin Blodgett vd. (1993), tüketicilerin hizmet telafisini adaletli algıladıklarında işletme hakkında daha az olumsuz kulaktan kulağa iletişim eğilimi gösterebildiklerini saptamışlardır. Bu görüşü destekleyen farklı çalışmalar da (Ro ve Olson, 2014), hizmet başarısızlığının olumsuz kulaktan kulağa iletişim üzerindeki rolünü araştırmış ve olumsuz kulaktan kulağa iletişimin hizmet telafi süreçlerinin başarılı ve adil bir şekilde yönetildiğinde azalabileceğini bulmuştur. Dolayısıyla adalet algısının ve boyutlarının farklı düzeylerine göre konaklama işletmeleri için olumsuz kulaktan kulağa iletişimin tüketiciler açısından farklılaşıp farklılaşmadığını incelemek anlamlı olabilecektir. Buna göre;

H1a: Farklı dağıtımsal adalet düzeylerine (düşük, yüksek, orta) göre ziyaretçilerin olumsuz kulaktan kulağa iletişim eğilimleri farklılaştırmaktadır.

H1b: Farklı etkileşimsel adalet düzeylerine (düşük, yüksek) göre ziyaretçilerin olumsuz kulaktan kulağa iletişim eğilimleri farklılaştırmaktadır. 
H1c: Farklı prosedürel adalet düzeylerine (düşük, yüksek) göre ziyaretçilerin olumsuz kulaktan kulağa iletişim eğilimleri farklılaştırmaktadır.

\section{Tekrar Satın Alma Eğilimi ve Adalet Algısı İlişkisi}

Jalilvand vd.'ne göre (2011), tüketiciler satın aldıkları mal veya hizmetten memnun olduklarında, tekrar satın alma veya markayı tavsiye etme eğiliminde olabilirler. Literatürde bu görüşü destekleyen birçok çalışma bulunmaktadır (Margee, 2008: 44). Kotler'e (2000: 184) göre, tekrar satın alma eğilimi müşteri beklentilerinin karşılanmasının sürekliliği ile sağlanmaktadır. Daha önce Gandhi-Arora ve Shaw (2001) tatmin ile tekrar satın alma arasındaki olumlu ilişkiyi turizm sektörü için saptamışlardır. Hatta yapılan çalışmalarda, konaklama işletmeleri gibi hizmet yoğun sektörlerde tatminin daha fazla tekrar satın almaya neden olabileceği de ortaya konmuştur (Karakaş vd., 2007). Tatmin, ilk hizmet sunumunda sağlanabileceği gibi telafi sonrası tatmin şeklinde de oluşabilmektedir (McCollough, 2009). Başarılı bir hizmet telafisi sonucu oluşan müşteri tatmini tekrar satın alma eğilimini de arttırabilecektir (Zeithaml ve Bitner, 2003). Ne var ki her türlü hizmet telafisi tüketicinin tatmin olmasını sağlamayabilir. Yalnızca müşteri şikâyetlerini iyi bir şekilde yöneten ve tüketicinin telafi sürecinde önem verdiği noktalara odaklanabilen işletmeler olumsuz olan müşteri tepkilerini olumluya çevirebileceklerdir (Zeithaml ve Bitner, 2003). Örneğin müşterinin telafi sürecinde algıladı̆̆ı adalet düzeyi, telafi sonrası tatmini etkileyen önemli etmenlerdendir (Smith vd., 1999; Blodgett vd., 1997).

Adalet algısı teorisine göre, hizmet hatalarını adil bir şekilde çözümleyebilen işletmeler müşterilerinin tatmin düzeylerini ve tekrar satın alma eğilimlerini artırabilecek, aynı müşterinin işletmeye sadık kalmasını sağlayabilecektir (Blodgett vd., 1993). Literatürde yer alan birçok çalışma adaletli algılanan hizmet telafisinin tekrar satın alma üzerine etkilerini incelemiştir (Blodgett vd., 1993; Yaseen vd., 2011). Dolayısıyla adalet algısı boyutlarının düzeylerine göre konaklama işletmeleri için de tekrar satın alma davranışının farklılaşıp farklılaşmadığını ölçmek önemli olabilecektir. Buna göre;

H2a: Farklı dağıtımsal adalet düzeylerine (düşük, yüksek, orta) göre ziyaretçilerin satın alma eğilimleri farklılaştırmaktadır.

H2b: Farklı etkileşimsel adalet düzeylerine (düşük, yüksek) göre ziyaretçilerin satın alma eğilimleri farklılaştırmaktadır.

H2c: Farklı prosedürel adalet düzeylerine (düşük, yüksek) göre ziyaretçilerin satın alma eğilimleri farklılaştırmaktadır.

Literatürde adalet algısı ve telafi sonrası davranışlar arasındaki ilişkiyi inceleyen çalışmalar oldukça fazladır (Lee, 2018). Hatta adalet algısı boyutlarının farklı değişkenler üzerine etkilerini inceleyen çalışmalar da giderek artmaktadır. Örneğin; Ekiz (2019), dağıtımsal, etkileşimsel ve prosedürel adalet boyutlarının ayrı ayrı sadakat üzerine etkilerini incelemiştir. Bu çalışmaların temel varsayımı her bir boyutun şikâyet sonrası davranışlar üzerine etkisinin farklı olabileceği yönündedir. Örneğin; Blodgett vd. (1997), algılanan adalet boyutlarının her birinin tekrar satın alma eğilimleri üzerine etkilerini incelemiş ve perakende mağazalarda etkileşimsel adalet boyutunun tekrar satın alma eğilimini en fazla etkileyen boyut olduğunu saptamışlardır. Farklı bir çalışma da (Smith vd., 1999) dağıtımsal adalet algısının hizmet telafisi sonrası müşteri tatminini ve tekrar satın alma eğilimlerini daha fazla etkilediği bulunmuştur. Ayrıca Ha ve Jang (2009), algılanan adaletin tüm boyutlarının restoran ortamında tekrar satın alma eğilimini etkileyebileceğini ortaya koymuşlardır. Algılanan adalet boyutlarının ayrı ayrı etkilerinin yanı sıra birbirleri ile etkileşimi de önemli olabilecektir. Böyle bir ayırıma gitmek, algılanan adalet boyutları bileşimlerinin şikâyet sonrası davranışlar üzerine etkilerini de ortaya koyabilecektir. Bu nedenle çalışmanın araştırma sorusu şu şekilde oluşturulmuştur;

AS: Dağıtımsal (yüksek, orta, düşük), prosedürel (yüksek, düşük) ve etkileşimsel (yüksek, düşük) adalet algısı boyutlarının farklı birleşimlerinden hangileri şikâyet sonrası davranışlarda (tekrar satın alma eğilimi ve olumsuz kulaktan kulağa iletişim) en fazla farklılaşmaya neden olmaktadır? 


\section{YÖNTEM}

Çalışmanın amacı konaklama işletmeleri ziyaretçilerinin şikâyet sonrası davranışları üzerine hizmet telafisi ölçüm yöntemlerinden biri olan adalet algısı boyutlarının etkilerini saptamaktır. Buna göre çalışmada adalet algısı boyutları olarak bilinen prosedürel, etkileşimsel ve dağıtımsal adalet algılarının; hata sonrası davranışlar olan konaklama işletmesinden tekrar hizmet satın alma eğilimi ve konaklama işletmesi ile ilgili olumsuz kulaktan kulağa iletişim üzerine etkileri saptanmaya çalışılmıştır. Buna göre oluşturulan araştırma modeli Şekil 1 de yer almaktadır.

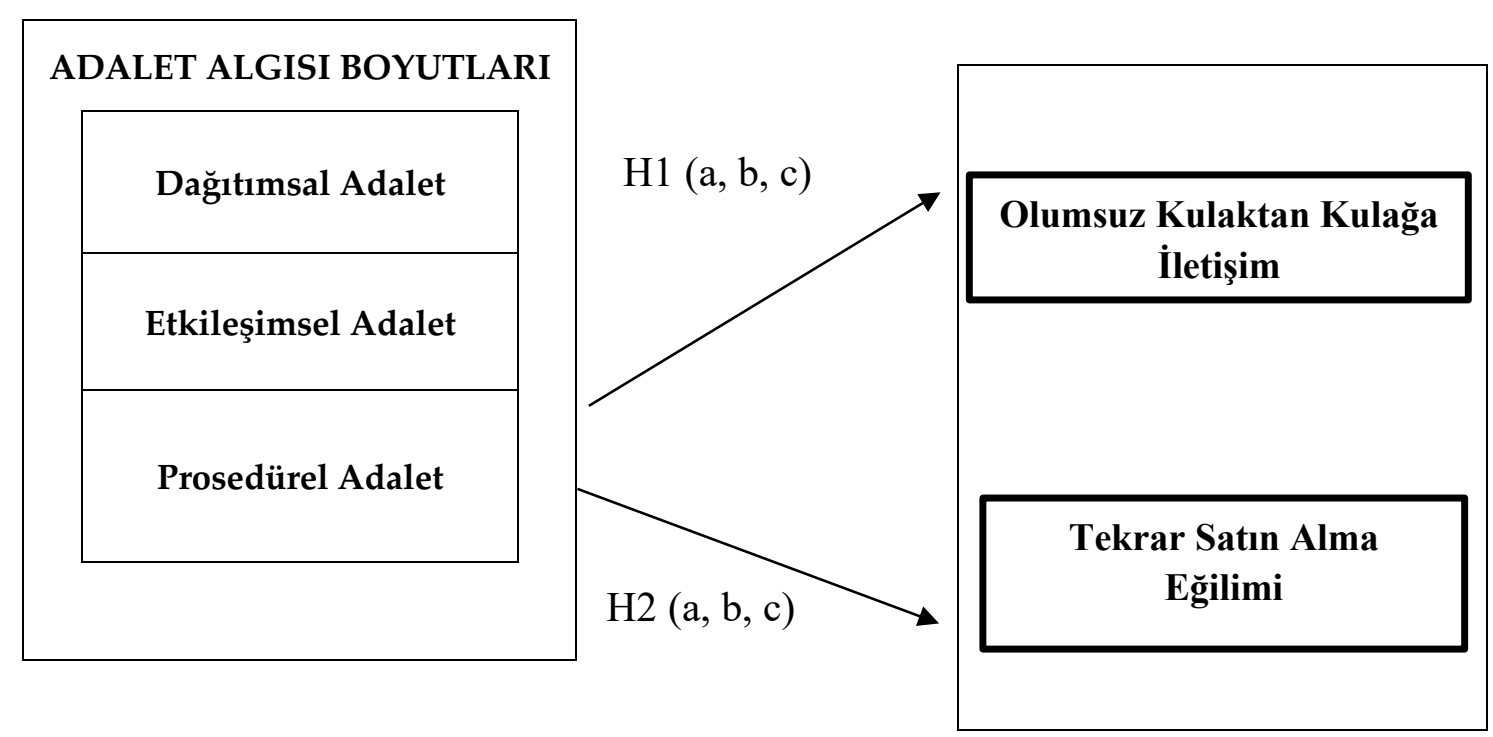

Şekil 1. Araştırma Modeli

\section{Deneysel Tasarımı ve Prosedür}

Çalışmanın hipotezlerini ve araştırma sorusunu test etmek amacıyla; dağıtımsal adaletin üç düzeyini (yüksek, orta, düşük), etkileşimsel adaletin iki düzeyini (yüksek, düşük) ve prosedürel adaletin iki düzeyini (yüksek, düşük) içeren $3 \times 2 \times 2$ gruplar arası, yarı-deneysel bir tasarım oluşturulmuştur (Cook ve Campbell, 1979). Deneysel yöntem; seçilen bağımsız değişkenlerin istenilen düzeyde ve miktarda manipüle edilmesi yolu ile bağımlı değişken üzerindeki etkilerini ölçmek için kullanılır (Brown ve Melamed, 1990:1). Sosyal bilimlerde deneysel çalışmaların temeli bağımsız değişkenler üzerinde yapılan manipülasyonlara dayanmaktadır. $X$ bağımsız değişkeni olarak adalet algısı boyutları üzerinde manipülasyonlar yapılarak $Y$ bağımlı değişkeni olarak olumsuz kulaktan kulağa iletişim ve tekrar satın alma eğilimi üzerinde yarattığı değişmeler gözlemlenmeye çalışılmıştır.

Buna göre, katılımcılardan kaldıkları otelde karşılaşmış olabilecekleri olumsuz bir duruma göre oluşturulmuş senaryoları okumaları istenmiştir, böylelikle içinde bulunmaları istenen durumu hayal etmeleri sağlanmaya çalışılmıştır (Kimmel, 2007). Senaryolarda yer alan dağıtımsal adaletin düzeyleri indirim miktarı değiştirilerek oluşturulmuştur. Etkileşimsel adaletin farklı düzeyleri ise çalışanların şikâyetçi olan müşterilere karşı tutum ve davranışları (kibar/kaba) değiştirilerek oluşturulmuştur. Prosedürel adaletin farklı düzeyleri de hizmet sağlayıcısının şikâyeti çözme hızı (otel müdürünün anında müşterinin yanına gelmesi ve sorunu çözüme ulaştırması/otel müdürünün gelmemesi ve müşteriye sorunu ertesi gün çözebileceğini iletmesi) ile ölçülmeye çalışılmıştır. Adalet algısı boyutlarının farklı düzeylerine göre on iki senaryo üretilmiştir. 


\section{Örneklem}

Çalışmada verilerin evrenden hızlı, kolay ve maliyetsiz olarak toplamasını sağlayan, tesadüfi olmayan örneklem yöntemlerinden kolayda örnekleme yöntemi kullanılmıştır. Deneysel tasarımda örneklem hacminin hesaplanmasında, parametre tahminlerinin doğru sonuç vermesi için önerilen modelde tahmin edilmesi gereken parametre sayısının on katı önerilmekte, bununla birlikte, gözlem sayısının en az 200 olması gerektiği belirtilmektedir (Kelloway, 1998). Bu çalışmada 15 parametre olduğu göz önüne alındığında örneklem hacminin en az 150 olması yeterli olacaktır. Ayrıca Gravetter ve Forzano (2013), deneysel ve faktöriyel tasarıma sahip çalışmalarda her bir deney tasarımı için 20-30 civarında örneklemin yeterli olacağını belirtmişlerdir. Araştırmada, cevaplayıcıların hata yapma olasılıkları, cevaplanmama oranı ve güvenilir olmayan verilerin olabileceği de öngörülerek uygulama sürecinde; her bir senaryo için 20-23 katılımcı olacak şekilde 300 anket formu dağıtılmış ve 270 adet geri dönmüştür. Örneklemin özellikleri incelendiğinde; 270 katılımcının $\% 54,1^{\prime}$ i kadın ve $\% 45,9^{\prime}$ u erkektir. $\% 44,1$ katılımcı lisans mezunu, \%24,1 lisansüstü mezunudur. Ayrıca katılımclların \%67'4'ü evli olmadıklarını ifade etmişlerdir. Katılımcıların \%40,7' si yüksek gelire sahip olduklarını belirtmişlerdir. Katılımciların \%58,5'inin yaş aralığ $20-29$ dur.

\section{Ölçekler}

Her bir yapının ölçümü için çoklu ifade içeren ölçekler oluşturulmuştur. Bu ifadeler daha önce literatürde kullanılan (örn. Blodgett vd., 1993; Blodgett vd., 1997; Sing, 1988) ve geçerlikleri test edilmiş ifadelerdir. Her bir ifade 5'li Likert tipi ölçek ile ölçülmüştür. Buna göre ifadeler karşısında yer alan uç değerler "kesinlikle katılıyorum/kesinlikle katılmıyorum" şeklindedir. Kullanılan ölçeklerin güvenilirliğinin test edilmesi için Alfa Modeli (Cronbach Alpha Coefficient) kullanılmıştır. Kullanılan ölçeklerin alfa değerlerinin kabul edilebilir düzeyde ( 0.70 üzeri) olduğu saptanmıştır.

\section{Manipülasyon Kontrolleri: Yapı Geçerliliği}

Yapı geçerliliğ̈inin ölçümü için öncelikle senaryonun yüzeysel geçerliliğini test etmek önemlidir. Bu doğrultuda Hacettepe Üniversitesi öğretim üyeleri arasından seçilen konaklama işletmelerinden müşteri olarak yararlanmış 24 öğretim üyesinin senaryonun gerçekçiliği üzerine yaptıkları değerlendirmeler ele alınmıştır. Yapılan ön uygulamalarda katılımcılara senaryoda aktarılan sorunun algılanan gerçeklik derecesi, böyle bir olay karşısında şikâyet edip etmeyecekleri ve aktarılan aksaklığın katılımcılar açısından önemi sorularak senaryonun geçerliliği sağlanmaya çalışılmıştır. Ön analizlerde katılımcıların bu sorulara verdikleri değerler gerçeğe yakın $(\alpha: 3.72$, standart sapma: 1.6$)$ ve önemli ( $\alpha$ : 4.08, standart sapma: 1) olduğunu göstermektedir. Buna göre senaryo tasarımının başarılı olduğu düşüncesi ile analizlere devam edilmiştir.

Yüzeysel geçerliliğe ek olarak ön testte manipülasyon kontrollerine yer verilmiştir ve amacı senaryolarda verilmek istenen farklı adalet algisı boyutlarının senaryoyu okuyan katılımcilar tarafından da farklı olarak algılanıp algılanmadığının kontrol edilmesidir. Bunun yanı sıra aynı yapıyı ölçen iki ölçeğin de benzer sonuçlar vermesi beklenir (convergent validity). Senaryoların arasındaki farkların (manipülasyonların) katılımcılar tarafından anlaşılıp anlaşılmadığının kontrolü için ANOVA testi kullanılmıştır. Örneğin, katılımcıların yüksek $(\bar{x}=3.99)$, orta $(\bar{x}=2.29)$ ve düşük $(\bar{x}=1.90)$ dağıtımsal adalet koşulları (senaryolar) için dağıtımsal adalet algıları (manipülasyon amaçlı ifadeler) anlamlı bir şekilde farklılaşmaktadır. Etkileşimsel ve Prosedürel adalet koşulları içinde benzer ANOVA testleri tekrarlanmış ve katılımcıların senaryo koşullarını anlamlı bir şekilde farklı algıladıkları ortaya konmuştur. Tüm bu ön analizler yapısal geçerliliğin kanıtları arasında yer almaktadır (Mattila ve Wirtz, 2001). 


\section{ANALIZ VE BULGULAR}

Araştırmanın ilk temel hipotezi (H1), adalet algısı boyutlarının farklı düzeylerine (düşük, yüksek, orta) göre ziyaretçilerin olumsuz kulaktan kulağa iletişim eğilimlerinin farklılaşıp farklılaşmadığını ölçmeye yönelik olarak oluşturulmuştur. Çalışmanın bir diğer temel hipotezi (H2) ise, adalet algısı boyutlarının farklı düzeylerine (düşük, yüksek, orta) göre ziyaretçilerin tekrar satın alma eğilimlerinin farklılaşıp farklılaşmadığını ölçmeye yönelik olarak oluşturulmuştur. Temel hipotezler daha sonra farklı adalet algısı boyutlarının etkilerini saptamak üzere üç farklı alt hipoteze (H1a,b,c ve H2a,b,c şeklinde) ayrılmıştır. H1a ve H2a dağıtımsal adalet algısının farklı düzeylerine (düşük, yüksek, orta) göre ziyaretçilerin olumsuz kulaktan kulağa iletişim ve tekrar satın alma eğilimlerinin farklılaşıp farklılaşmadığını ölçmeye yönelik olarak oluşturulmuştur. Dağıtımsal adalet algısının olumsuz kulaktan kulağa iletişim ve tekrar satın alma eğilimlerinin üzerine etkilerini görebilmek adına ANOVA testi uygulanmıştır (Tablo-1).

Tablo 1. Tekrar Satın Alma ve Olumsuz Kulaktan Kulağa İletişim Eğilimlerinin Dağıtımsal Adalet Algısı Düzeylerine Göre Farklılaşması (ANOVA Testi Sonuçları)

\begin{tabular}{cccccc}
\hline & Dağıtımsal Adalet & & & & \\
Bağımlı Değişkenler & Düzeyleri & $(\bar{X})$ & SS & $F$ & $p$ \\
\hline Tekrar Satın Alma & Yüksek & 2.69 & 1.37 & & \\
Eğilimi & Orta & 2.85 & 1.32 & 1.598 & .218 \\
& Düşǚk & 2.51 & 1.17 & & \\
& Total & 2.68 & 1.29 & & \\
& & & & & \\
& Yüksek & 3.10 & 1.34 & & \\
Olumsuz Kulaktan & Orta & 3.47 & 1.18 & & \\
Kulağa İletişim & Dïşük & 3.46 & 1.12 & 2.580 & .073 \\
& Total & 3.34 & 1.22 & & \\
\hline
\end{tabular}

$p<.05$

Elde edilen bulgulara göre dağıtımsal adaletin yüksek, orta ve düşük olduğu durumlarda ziyaretçilerin olumsuz kulaktan kulağa iletişim $(\mathrm{p}=073 ; \mathrm{p}>.05)$ ve tekrar satın alma eğilimleri $(\mathrm{p}=.218 ; \mathrm{p}>.05)$ farklılaşmamaktadır. Başka bir ifadeyle, ziyaretçilerin şikâyetleri sonrasında elde ettikleri indirim, geri ödeme gibi fiziki çıktının düzeyine göre tekrar satın alma eğilimlerinde artış veya olumsuz kulaktan kulağa iletişim eğilimlerinde de azalma meydana gelmeyebilecektir.

H1b ve H2b etkileşimsel adalet algısının farklı düzeylerine (düşük, yüksek) göre ziyaretçilerin olumsuz kulaktan kulağa iletişim ve tekrar satın alma eğilimlerinin farklılaşıp farklılaşmadığını ölçmeye yönelik olarak oluşturulmuştur. Etkileşimsel adalet algısının olumsuz kulaktan kulağa iletişim ve tekrar satın alma eğilimlerinin üzerine etkilerini görebilmek adına T-testi uygulanmıştır (Tablo-2).

Elde edilen bulgulara göre etkileşimsel adaletin yüksek ve düşük olduğu durumlarda ziyaretçilerin olumsuz kulaktan kulağa iletişim $(\mathrm{p}=000 ;<.05)$ ve tekrar satın alma eğilimleri $(\mathrm{p}=.000 ;<.05)$ anlamlı bir şekilde farklılaşmaktadır. Başka bir ifadeyle, ziyaretçilerin şikâyetleri sonrasında elde ettikleri güler yüzlü ve kibar çalışanlar aracıllı̆̆ı ile çözüm bulma gibi etkileşimin düzeyine göre tekrar satın alma eğilimlerinde artış $(\bar{x}=3.15)$ ve olumsuz kulaktan kulağa iletişim eğilimlerinde de azalma ( $\bar{x}=2.98)$ meydana gelebilecektir.

Çalışmanın diğer alt hipotezleri (H1c ve H2c) prosedürel adalet algısının şikâyet sonrası davranışlar üzerine etkileri ölçmeye yönelik olarak oluşturulmuştur. Buna göre prosedürel adalet algısının iki farklı düzeyine (düşük, yüksek) göre ziyaretçilerin olumsuz kulaktan kulağa iletişim ve tekrar satın alma eğilimlerinin farklılaşıp farklılaşmadığını ölçmeye yönelik olarak t-testi uygulanmıştır (Tablo-2). 
Tablo 2. Tekrar Satın Alma ve Olumsuz Kulaktan Kulağa İletişim Eğilimlerinin Etkileşimsel Adalet Algısı Düzeylerine Göre Farklılaşması (T-Testi Sonuçları)

\begin{tabular}{|c|c|c|c|c|c|c|}
\hline Bağımlı Değişkenler & $\begin{array}{c}\text { Etkileşimsel Adalet } \\
\text { Düzeyleri }\end{array}$ & $(\bar{X})$ & ss & $\begin{array}{c}\text { Varyans } \\
\text { Homojenliği }\end{array}$ & $t$ & $p$ \\
\hline Tekrar Satın Alma & Yüksek & 3,1546 & 1,12389 & & & \\
\hline \multirow[t]{2}{*}{ Eğilimi } & Düşük & 2,2174 & 1,28902 & ,029 & 6,440 &, $000^{*}$ \\
\hline & Total & 2,6860 & 1,29512 & & & \\
\hline \multirow{3}{*}{$\begin{array}{l}\text { Olumsuz Kulaktan } \\
\text { Kulağa İletişim }\end{array}$} & Yüksek & 2,9828 & 1,07136 & & & \\
\hline & Düşük & 3,7107 & 1,26806 & ,025 & $-5,019$ &, $000^{*}$ \\
\hline & Total & 3,3468 & 1,22708 & & & \\
\hline \multirow{4}{*}{$\begin{array}{c}\text { Bağımlı Değişkenler } \\
\text { Tekrar Satın Alma } \\
\text { Eğilim }\end{array}$} & $\begin{array}{c}\text { Prosedürel Adalet } \\
\text { Düzeyleri }\end{array}$ & $(\bar{X})$ & ss & $\begin{array}{c}\text { Varyans } \\
\text { Homojenliği }\end{array}$ & $t$ & $p$ \\
\hline & Yüksek & 2,8468 & 1,32314 & & & \\
\hline & Düşük & 2,5276 & 1,25162 & ,004 & 4,960 &, $043^{*}$ \\
\hline & Total & 2,6860 & 1,29512 & & & \\
\hline \multirow{3}{*}{$\begin{array}{l}\text { Olumsuz Kulaktan } \\
\text { Kulağa İletişim }\end{array}$} & Yüksek & 3,1915 & 1,31718 & & & \\
\hline & Düşük & 3,4997 & 1,11514 & ,003 & $-4,020$ &, $039^{*}$ \\
\hline & Total & 3,3468 & 1,22708 & & & \\
\hline
\end{tabular}

Elde edilen bulgulara göre prosedürel adaletin yüksek ve düşük olduğu durumlarda ziyaretçilerin olumsuz kulaktan kulağa iletişim $(\mathrm{p}=039 ;<.05)$ ve tekrar satın alma eğilimleri $(\mathrm{p}=.043 ;<.05)$ anlamlı bir şekilde farklılaşmaktadır. Başka bir ifadeyle, ziyaretçilerin şikâyetleri sonrasında elde ettikleri hızlı ve düzgün çözüm yolları gibi işletmenin telafi politikalarına ilişkin düzeylerdeki farklılaşma tekrar satın alma eğilimlerinde artış ( $\bar{x}=2.84)$ ve olumsuz kulaktan kulağa iletişim eğilimlerinde de azalmaya $(\bar{x}=3.19)$ neden olabilecektir (Tablo-2).

Ancak her zaman tüketici söz konusu boyutları tek başına değerlendirmemektedir. Örneğin ziyaretçiler, telafi politikaları ile birlikte çalışan ile arasındaki etkileşim veya elde edilen fiziki tazminatları birlikte değerlendirmeye alabilecektir. Bu nedenle adalet algısı boyutlarından oluşan bileşimlerin şikâyet sonrası davranışlar üzerine etkilerini incelemek için de ayrıca ANOVA testleri yapılmıştır (Tablo-3).

Tablo 3. Adalet Algısı Boyutlarının Birbirleri ile Etkileşiminin Tekrar Satın Alma Eğilimi Üzerine Etkileri (ANOVA Testi Sonuçları)

\begin{tabular}{lcc}
\hline Bağımlı Değişken: Tekrar Satın Alma Eğilimi & $F$ & $p$ \\
\hline Dağıtımsal adalet * Etkileşimsel adalet & 1,578 &, 208 \\
Dağıtımsal adalet * Prosodürel adalet &, 241 &, 786 \\
Etkileşimsel adalet *Prosodürel adalet & 5,427 &, $\mathbf{0 2 1}$ \\
Dağıtımsal adalet* Etkileşimsel adalet * Prosodürel adalet & $\mathbf{4 , 4 8 8}$ &, $\mathbf{0 1 2}^{*}$
\end{tabular}

${ }^{{ }^{*} p<.05}$

Yapılan analiz sonuçlarına göre, dağıtımsal adalet, etkileşimsel veya prosedürel adalet ile birlikte değerlendirilse dahi tekrar satın alma eğiliminde bir farklılaşmaya neden olamayacağını $(p=.208 ;>.05)$ göstermektedir. Bunun yanı sıra etkileşimsel adalet algısı düzeylerindeki farklılaşma ile prosedürel adalet algısı düzeylerindeki farklılaşma, tekrar satın alma eğilimi üzerine etki edebilmekte, 
farklılaşmaya neden olabilmektedir $(\mathrm{p}=, 021 ;<.05)$. Dağıtımsal adalet düzeylerinin yalnızca adalet algıSı boyutlarının tamamının birlikte ele alındığı değerlendirmelerde tekrar satın alma eğiliminde farklılaşmaya neden olabileceği saptanmıştır. Bu farklılaşmaların hangi düzeylerden kaynaklandığını anlayabilmek için Tamhane posthoc testi uygulanmıştır (Tablo-4).

Tablo 4. Dağıtımsal, Prosedürel ve Etkileşimsel Adalet Algı Boyutlarının Tekrar Satın Alma Eğilimi Üzerine Etkileri (Tamhane Posthoc Testi Sonuçları)

\begin{tabular}{|c|c|c|c|}
\hline $\begin{array}{l}\text { Bağımlı Değişken: Tekrar Satın Alma } \\
\text { Eğilimi }\end{array}$ & $\begin{array}{c}\text { Dağıtımsal, Etkileşimsel ve } \\
\text { Prosedürel Adalet Boyutları } \\
\text { Etkileşimleri }\end{array}$ & $(\bar{X})$ & $p$ \\
\hline \multirow{2}{*}{$\begin{array}{c}\text { Dağıtımsal }\left(\mathrm{Y}^{*}\right) \text { Etkileşimsel }(\mathrm{Y}) \text {, } \\
\text { Prosedürel }(\mathrm{Y}) \\
(\bar{X}=3,42)\end{array}$} & $\begin{array}{l}\text { Dağıtımsal (D) } \\
\text { Prosedürel (Y) } \\
\text { Etkileşimsel (D) } \\
\end{array}$ & 1,62 & 007, \\
\hline & $\begin{array}{l}\text { Dağıtımsal (Y) } \\
\text { Prosedürel (D), } \\
\text { Etkileşimsel (D) }\end{array}$ & 1,81 & 040 \\
\hline \multirow{2}{*}{$\begin{array}{c}\text { Dağıtımsal }\left(\mathrm{O}^{* * *}\right) \text {, Prosedürel(D), } \\
\text { Etkileşimsel(Y) } \\
(\overline{\boldsymbol{X}}=3,44)\end{array}$} & $\begin{array}{l}\text { Dağıtımsal (Y) } \\
\text { Prosedürel(Y) } \\
\text { Etkileşimsel (D) }\end{array}$ & 1,81 & 040 \\
\hline & $\begin{array}{l}\text { Dağıtımsal (D) } \\
\text { Prosedürel(Y) } \\
\text { Etkileşimsel (D) }\end{array}$ & 1,62 & 008 \\
\hline \multirow{2}{*}{$\begin{array}{c}\text { Dağıtımsal }\left(D^{* *}\right) \text { Prosedürel }(Y) \\
\text { Etkileşimsel }(Y) \\
(\bar{X}=3,60)\end{array}$} & $\begin{array}{l}\text { Dağıtımsal (D) } \\
\text { Prosedürel(Y) } \\
\text { Etkileşimsel (D) } \\
\end{array}$ & 1,62 & ,001 \\
\hline & $\begin{array}{l}\text { Dağıtımsal(Y) } \\
\text { Prosedürel(D) } \\
\text { Etkileşimsel (D) }\end{array}$ & 1,81 & 007, \\
\hline
\end{tabular}

Tamhane posthoc testinin sonuçlarına göre; dăğttımsal adaletin düşük, prosedürel ve etkileşimsel adalet algısının yüksek olduğu bileşim ziyaretçilerin en fazla tekrar satın alma ĕ̆ilimini artırabilecek bileşimdir $(\bar{X}=3,60)$. Bir diğer ifade ile dağıtımsal adaletin diğer iki boyutun yüksek olduğu koşullarda düşük olması tüketicinin yine de tekrar satın alma eğilimi göstermesini sağlayabilmektedir. Bunun anlamı, konaklama işletmelerinde indirim veya para iadesi gibi fiziki telafilerin düzeyi düşük olsa dahi, ilişki odaklı ve şikâyetin çözülme hızı, yetkilinin işletmede bulunması gibi prosedürel telafiler müşterinin tekrar satın almasını artırabilecektir.

Benzer şekilde adalet algısı boyutlarının birliktelikleri ziyaretçilerin olumsuz kulaktan kulağa iletişim eğilimlerini de etkileyebilecektir. Adalet algısı boyutlarının birbirleri ile etkileşimlerinin olumsuz kulaktan kulağa iletişim üzerine etkilerini incelemek için ANOVA testi yapılmıştır (Tablo-5).

Tablo 5. Adalet Algısı Boyutlarının Olumsuz Kulaktan Kulağa İletişim Üzerine Etkileri (ANOVA Testi Sonuçları)

\begin{tabular}{lcc}
\hline Bağımlı Değişken: Olumsuz Kulaktan Kulağa İletişim & $F$ & $p$ \\
\hline Dağıtımsal adalet * Etkileşimsel adalet & 1,662 &, 192 \\
Dağıttımsal adalet * Prosodürel adalet & 1,968 &, 142 \\
Etkileşimsel adalet * Prosodürel adalet & $\mathbf{7 , 7 2 3}$ & $\mathbf{, 0 0 6}$ \\
Dağıtımsal adalet * Etkileşimsel adalet * Prosodürel adalet & $\mathbf{3 , 1 0 3}$ & $\mathbf{, 0 4 7 ^ { * }}$ \\
\hline
\end{tabular}

*Birlikte etkileşimlerini ifade etmektedir. 
ANOVA sonuçlarına göre, yine dağıtımsal adalet, etkileşimsel veya prosedürel adalet ile birlikte dahi olumsuz kulaktan kulağa iletişim eğiliminde bir farklılaşmaya neden olamamaktadır ( $p=.192,>.05$; $\mathrm{p}=.142,>.05)$. Bunun yanı sıra etkileşimsel adalet algısı düzeylerindeki farklılaşma ile prosedürel adalet algısı düzeylerindeki farklılaşma bir araya geldiğinde olumsuz kulaktan kulağa iletişimde farklılaşmaya neden olabilmektedir $(p=.006,<.05)$. Adalet algısı boyutlarının tamamının birlikte ele alındığında dağıtımsal adalet düzeyleri tekrar satın alma eğiliminde farklılaşmaya neden olabilecektir $(\mathrm{p}=.047,<.05)$. Bu farklılaşmaların hangi düzeylerden kaynaklandı̆̆ını anlayabilmek için Tamhane posthoc test uygulanmıştır (Tablo-6).

Tablo 6. Dağıtımsal, Prosedürel ve Etkileşimsel Adalet Algısı Boyutlarının Olumsuz Kulaktan Kulağa İletişim Üzerine Etkileri (Tamhane Posthoc Testi Sonuçları)

\begin{tabular}{|c|c|c|c|}
\hline $\begin{array}{l}\text { Bağımlı Değişken: Olumsuz } \\
\text { Kulaktan Kulağa İletişim }\end{array}$ & $\begin{array}{l}\text { Dağıtımsal, Etkileşimsel ve } \\
\text { Prosedürel Adalet Boyutları } \\
\text { Etkileşimleri }\end{array}$ & $(\bar{X})$ & $p$ \\
\hline $\begin{array}{c}\text { Dağıtımsal }\left(D^{* *}\right), \text { Etkileşimsel }\left(Y^{*}\right) \\
\text { Prosedürel }\left(Y^{*}\right) \\
(\bar{X}=2,40)\end{array}$ & $\begin{array}{l}\text { Dağıtımsal (Y) } \\
\text { Prosedürel(Y) } \\
\text { Etkileşimsel(Y) }\end{array}$ & 2,31 & ,001 \\
\hline $\begin{array}{c}\text { Dağıtımsal }\left(D^{* *}\right), \text { Prosedürel }\left(Y^{*}\right) \\
\text { Etkileşimsel }\left(D^{* *}\right) \\
(\bar{X}=4,23)\end{array}$ & $\begin{array}{l}\text { Dağıtımsal (D) } \\
\text { Prosedürel(Y) } \\
\text { Etkileşimsel(Y) }\end{array}$ & 2,40 & ,002 \\
\hline
\end{tabular}

Tamhane posthoc testinin sonuçlarına göre; dağıtımsal adaletin düşük, etkileşimsel ve prosedürel adalet algısının yüksek olduğu bileşim ziyaretçilerin en az olumsuz kulaktan kulă̆a iletişim eğilimi gösterdikleri bileşimdir $(\overline{\boldsymbol{X}}=\mathbf{2}, \mathbf{4 0})$. Bir diğer ifade ile dağıtımsal adalet düşük olarak algılansa dahi etkileşimsel ve prosedürel adaletin yüksek algılandığı bir senaryoda ziyaretçiler daha az olumsuz kulaktan kulağa iletişimde bulunabileceklerdir.

Özetle adalet algısı boyutlarının tek başına etkileri incelendiğinde, konaklama işletmelerinde yaşanan bir problem sonucunda ziyaretçilerin elde ettikleri somut telafilerdense, çalışan ile etkileşim ve çözüm sürecindeki yerleşmiş kurallar veya hızlı çözüme olanak sağlayan politikalar daha fazla tekrar satın alma eğilimi sağlayabilecek, bunun yanı sıra da olumsuz kulaktan kulağa iletişimi azaltabilecektir. Ancak tüketiciler çoğu zaman adalet algısı boyutlarını birlikte değerlendirmektedirler. Buna göre, şikâyet sonrası elde edecekleri finansal telafiler, bu telafinin sunulması esnasında çalışanın tutum ve davranışları ile işletmenin telafi sunma sürecinde uyguladı̆̆ı prosedürler birlikte değerlendirilmektedir. Çalışmanın bu yöndeki bulguları da göstermiştir ki, firma tüketicinin zararını finansal olarak karşılamasa dahi çalışanların telafi sürecinde kibar, sevecen veya yardımsever davranışları ile bu süreçte düzgün işleyen kuralların olması tekrar satın alma davranışını artırabilecek ve olumsuz kulaktan kulağa iletişimi de azaltabilecektir.

\section{SONUÇ VE TARTIŞMA}

Teorik Bulgular: Çalışmanın sonuçlarına göre, hizmet sağlayıcının telafi sürecinde tüketicilerle kurduğu ilişki tüketicilerin telafi sonrasında olumlu davranışlar göstermesine neden olabilecek, tekrar satın alma veya olumsuz kulaktan kulağa eğilimlerini farklılaştırabilecektir. Bu sonuçlar, hizmet işletmelerinde çalışanların tutumunun önemini vurgulamaktadır (Bowen ve Lawler, 1995). Bunun yanı sıra, telafi süreci içerisinde yer alan prosedürlerin, kuralların tüketici tarafından adaletli algılanma düzeyine göre de tekrar satın alma ve olumsuz kulaktan kulağa iletişim eğilimi farklılaşabilecektir. Çalışmanın sonuçları aynı zamanda farklı boyutların farklı etkilere sahip olabileceğine yönelik çalışmalara (Mansori vd., 2014) da katkı sağlamaktadır. 
Çalışmanın diğer bulgularına göre, etkileşimsel ve dağıtımsal adaletin birlikteliği tüketicinin tekrar satın alam veya olumsuz kulaktan kulağa iletişim eğiliminde bir farklılaşmaya neden olmadığı görülmüştür. Benzer şekilde, prosedürel ve dağıtımsal adaletin birlikteliği de tüketicinin tekrar satın alma veya olumsuz kulaktan kulağa iletişim eğiliminde bir farklılaşmaya neden olmamaktadır. Ancak etkileşimsel ve prosedürel adalet boyutlarının teker teker etkilerinin yanı sıra, birliktelikleri de şikâyet sonrası davranışları farklılaştırabilecektir. Benzer şeklide algılanan adaleti oluşturan etkileşimsel, prosedürel ve dağıtımsal adalet boyutların üçlü bileşimi de tekrar satın alma niyeti ve olumsuz kulaktan kulağa iletişim üzerinde etkiye sahiptir. Bunun anlamı, tek başına çalışanların tutumu veya tek başına prosedürlerin düzgün işlemesi, somut tazminatların (geri ödeme vb.) tüketiciye ödenmemesini telafi edemeyebilir. Ancak somut tazminatın ödenmemesi durumunu etkileşimsel ve prosedürel adalet boyutlarının birlikte yüksek algılanması telafi edebilecektir. Başka bir ifade ile ulaşılan kritik sonuç; konaklama işletmeleri her ne kadar para iadesi gibi somut telafileri yerine getirse de çalışanlarının müşteri ile olan ilişkisini ve telafi sürecinde yer alan kuralları iyileştirmeden tüketicilerin tekrar satın almalarını veya olumsuz kulaktan kulağa iletişimlerini azaltmalarını sağlayamayabilecektir. Bunun nedeni olarak, konaklama işletmelerinin hizmet yoğun bir sektör olması gösterilebilir. Günümüzde birçok işletme hizmet yoğun üretime geçmiş ve farklılaşma stratejileri olarak da sundukları hizmetlere daha fazla odaklanmaya başlamışlardır. Bu nedenledir ki konaklama işletmelerinde yaşanan hatalar sonrası telafi sürecinde sunulan fiziki çıktılardansa çalışanın etkileşimi, kibar yaklaşımı, işletmenin prosedürlerinin ve kurallarının düzgün işlemesi daha önemli hale gelebilmektedir.

Yönetimsel Katkılar: Temel olarak bu çalışma hizmet telafisini yöneticilerin bütünsel bir bakış açısı ile ele almaların önermektedir. Buna göre, konaklama işletmeleri yalnızca geri ödeme gibi somut telafiler ile tüketicilerinin tekrar ziyaret etmelerini artıramayabilir veya olumsuz kulaktan kulağa iletişimlerini azaltamayabilirler. Dolayısıyla konaklama işletmeleri yalnızca somut telafilere odaklanmak yerine hizmet baskın bir sektörde olduklarını unutmayıp müşteri ile yüz yüze iletişim kuran çalışanlarına odaklanmalıdır. Bu doğrultuda çalışanların işe alım süreçleri oldukça önem taşımaktadır. Kalifiye eleman işe alımı ve daha sonra bu elemanların sürekli eğitimleri oldukça önemlidir. Örneğin, çalışanların bir hata ile karşılaşan müşteriye nasıl davranması gerektiği, müşteriye olan yaklaşımı konusunda sürekli eğitimler verilebilir ve ödüllendirme politikaları uygulanabilir. Hizmet başarı döngüsü eğitimin yanı sıra çalışanların tatmin olması ile sağlanabilir. Çalışma saatlerinin esnekliği, ödüllendirme, ayın elemanı seçimi, küçük hediyeler çalışanların daha mutlu olmasını sağlamak müşteriler ile iletişiminin iyileşmesini sağlayabilecektir. Aynı zamanda konaklama işletmeleri kuralların (prosedürlerin) düzgün işlemesi konusunda yönetimsel kararlar almaları gerekebilmektedir. Telafi süreci belli kurallara bağlanarak standardize edilmeye çalışılabilir. Hizmet hatası ile karşılaşan bir müşterinin şikâyetini bildirdiği andan çözüm anına kadar olan basamaklar kurallar ve usullerle belirgin hale getirilerek, çalışanın kişisel kararlarından çıartılması sağlanabilir.

Çalışmanın senaryolar ile yapılmış olması önemli bir kısıtıdır, gerçek bir alan çalışması, tamamlayıcı olabilecektir. Bir başka kısıt, prosedürel adaletin yalnızca hizmet yöneticisinin şikâyeti çözme hızı ile ele alınmaktadır. Ek çalışmalarda farklı bakış açılarıyla genişletilebilir. Çalışmanın bir diğer kısıtı, demografik özelliklerin dikkate alınmamasıdır. İlerleyen çalışmalarda demografik özellikler dikkate alınarak, anlamlı bir fark olup olmadığı araştırılabilir.

\section{KAYNAKÇA}

Baumeister, R. F., Bratslavsky, E., Finkenauer, C. and Vohs, K. D. (2001). Bad is Stronger Than Good. Review of General Psychology, 5: 323-370.

Bell, C.R. and Zemke, R.E. (1987). Service Breakdown: The Road to Recovery. Management Review, 76(10): 32-35.

Blodgett J.G., Granbois D.H. and Walters R.G. (1993). The Effects of Perceived Justice on Complainants' Negative Word-Of-Mouth Behavior and Repatronage Intentions. Journal of Retailing, 69(4): 399- 427. 
Blodgett, J.G., Hill, J.D. and Tax, S.S. (1997). The Effects of Distributive, Procedural and Interactional Justice on Postcomplaint Behaviour. Journal of Retailing, 73(2): 185-210.

Bowen, D. E. and Lawler, E. E. (1995). Empowering Service Employees. Sloan Management Review, 36: 73-84.

Brown, S.R. and Melamed, L. E. (1990). Experimental Design and Analysis. USA: Sage Publication. 5: 109126.

Carrillo, I., Svensson, G. and Neira, M. (2019). The İmpact Of Perceived Justice on Satisfaction and Behavioral İntentions İn Service Encounters - A Comparison and Validation Study. International Journal of Quality and Service Sciences, 11(3): 378-394.

Chen, P. and Kim, Y. G. (2019). Role of The Perceived Justice of Service Recovery: A Comparison of First-Time and Repeat Visitors. Tourism and Hospitality Research, 19(1): 98-111.

Chih-Hung, P. A. I., Kuo-Min, K. O. and Santos, T. (2019). A Study of The Effect of Service Recovery on Customer Loyalty Based on Marketing Word of Mouth in Tourism Industry. Revista de Cercetare si Interventie Sociala, 64-74.

Clemmer, E. C. and Schneider, B. (1996). Fair service, (Eds.) T. A. Swartz, D. E. Bowen, and S. W. Brown: Advances In Services Marketing and Management, 5: 109-126. Greenwich, CT: JAI Press.

Cook, T.D. and Campbell, D.T. (1979). Quasi-Experimentation: Design and Analysis for Field Settings. Chicago, ILL: Rand McNa lly.

Ding, M.C. and Lii, Y.S. (2016). Handling Online Service Recovery: Effects of Perceived Justice on Online Games. Telematics and Informatics, 33(4): 881-895.

Ekiz, E. (2019). How Constraints on Tourist Complaints Affect Perceptions of Justice and Intentions of Loyalty: Case of Tourists from China Visiting Turkey. Journal of Global Business Insights, 4(1): 1-17.

Gandhi-Arora, R. and Shaw. R. (2001). Antecedents of Recommending Infrequently Purchased Services: A Conceptualisation and An Empirical Analysis. Erişim Tarihi: 12.09 .2017 http//:130.195.95.71:8081/WWW/ANZMAC2001/anzmac/AUTHORS/AuthorG.htm - 6k -,.

Gravetter, F.J. and Forzano, L.B. (2013). Research Method for The Behavioral Science (5th. ed.). USA: Cengage Learning.

Grönroos, C. (1990). Relationship Marketing Approach to the Marketing Function in Service Context: The Marketing and Organizational Behaviour Influence. Journal of Business Research, 20(1): 3-20.

Ha, J. and Jang, S. (2009). Perceived Justice in Service Recovery and Behavioral İntentions: The Role of Relationship Quality. International Journal of Hospitality Management, 28: 319-327.

Harun, A., Rokonuzzaman, M., Prybutok, G., and Prybutok, V. R. (2019). Determinants of Banking Consumers' Engagement in Post Service Failure Positive Word-Of-Mouth: Examining Mediating Mechanisms. International Journal of Bank Marketing, 37(2): 621-645.

Haverila, M.J. and Naumann, E. (2009). Customer Satisfaction and Complaints: Is There a Relotionship. Review of Business Research, 9: 74.

Jalilvand, M, R., Samiei, N. and Mahdavinia, S, H. (2011). The Effect of Brand Equity Components on Purchase Intention. International Business and Management, 2(2): 149-158.

Karakaş, B., Bircan, B. ve Gök, O. (2007). Hizmet Sektöründe İlişki Pazarlaması: Butik Oteller ve 5 Yıldızlı Oteller Üzerine Karşılaştırmalı Bir Araştırma, Ege Akademik Bakış, 7: 3-18.

Kelloway, E. K. (1998). Using Lisrel For Structural Equation Modeling: A Researcher's Guide. Thousand Oaks: Sage Publications. 
Kimmel, A.J. (2007). Ethical Issues in Behavioral Research: Basic and Applied Perspective. Blackwell Publishing.

Kotler, P. (2000). Pazarlama Yönetimi, (Çev. Muallimoğulları, N.) Kırklareli: Milenyum Baskı, Beta.

Kotler, P. and Armstrong, G. (2004). Principles of Marketing, New Jersey: Pearson Education International.

Kelley, S. W., Hoffman, D. K. and Davis, M. A. (1994). A Typology of Retail Failures and Recovery. Journal of Retailing, 69 (40): 429-452.

Lee, S. H. (2018). Guest Preferences for Service Recovery Procedures: Conjoint Analysis. Journal of Hospitality and Tourism Insights, 1(3): 276-288.

Margee, H. (2008). Developing A Conceptual Model for Repurchase Intention in The Performing Arts: The Role of Emotion, Core Service and Service Delivery. International Journal of Arts Management, 10(2): 40-55.

Mansori, S., Tying, G.G. and Ismail, Z.M.M. (2014). Service Recovery, Satisfaction Con Customers' Post Service Behavior in The Malaysian Banking Sector. Management Dynamics in the Knowledge Economy, 2(1): $5-20$.

Mattila, A. S. and Wirtz, J. (2001). Consumer Complaining to Firms: The Determinants of Channel Choice. Journal of Service Research, 18(2): 147-155.

McCollough, M. A. (2009). The Recovery Paradox: The Effect of Recovery Performance and Service Failure Severity on Post-Recovery Customer Satisfaction. Academy of Marketing Studies Journal, 13(1): 89104.

Migacz, S.J., Zou, S. and Petrick, J.F. (2018). The "Terminal" Effects of Service Failure on Airlines: Examining Service Recovery with Justice Theory. Journal of Travel Research, 57(1): 83-98.

Nikbin, D., Ismail, I., Marimuthu, M. and Jalalkamali, M. (2010). Perceived Justice İn Service Recovery and Recovery Satisfaction: The Moderating Role of Corporate İmage. International Journal of Marketing Studies, 2(2): 47.

Ro, H. and Olson, E.D. (2014). The Effects of Social Justice and Stigma-Consciousness on Gay Customers' Service Recovery Evaluation. Journal of Business Research, 67 (6): 1162-1169.

Sengupta, A.S., Balaji, M. and Krishnan, B.C. (2015). How Customers Cope with Service Failure? A Study of Brand Reputation and Customer Satisfaction. Journal of Business Research, 68(3): 665-674.

Sparks, B.A. and Mc-Coll-Kennedy, J.R., (2001). Justice Strategy Options Forincreased Customer Satisfactionin a Services Recovery Setting. Journal of Business Research, 54.

Smith, A.K., Bolton, R.N. and Wagner, J. (1999). A Model of Customer Satisfaction with Service Encounters Involving Failure and Recovery. Journal of Marketing Research, 36(3): 356-72.

Zemke, R. and Anderson, K. (2007). Delivering Knock Your Socks Off Service. New York: American Marketing Association Publication.

Zeithaml, V. and Bitner, M.J. (2003). Services Marketing: Integrating Customer Focus Across the Firm. New York: McGraw-Hill. 